\title{
The pernicious effects of contaminated data in risk management
}

\author{
Laurent Frésard ${ }^{\mathrm{a}}$, Christophe Pérignon ${ }^{\mathrm{a}, *}$, Anders Wilhelmsson ${ }^{\mathrm{b}}$ \\ ${ }^{a}$ HEC Paris, 1 Rue de la Libération, 78351 Jouy-en-Josas, France \\ ${ }^{\mathrm{b}}$ Lund University, Department of Economics, PO Box 7080, 22007 Lund, Sweden
}

\section{A R T I C L E I N F O}

\section{Article history:}

Received 14 October 2010

Accepted 16 February 2011

Available online 23 February 2011

\section{JEL classification:}

G21

G28

G32

Keywords:

Regulatory capital

Proprietary trading

Backtesting

Value-at-risk

Profit-and-loss

\begin{abstract}
A B S T R A C T
Banks hold capital to guard against unexpected surges in losses and long freezes in financial markets. The minimum level of capital is set by banking regulators as a function of the banks' own estimates of their risk exposures. As a result, a great challenge for both banks and regulators is to validate internal risk models. We show that a large fraction of US and international banks uses contaminated data when testing their models. In particular, most banks validate their market risk model using profit-and-loss (P/L) data that include fees and commissions and intraday trading revenues. This practice is inconsistent with the definition of the employed market risk measure. Using both bank data and simulations, we find that data contamination has dramatic implications for model validation and can lead to the acceptance of misspecified risk models. Moreover, our estimates suggest that the use of contaminated data can significantly reduce (market-risk induced) regulatory capital.
\end{abstract}

(c) 2011 Elsevier B.V. All rights reserved.

\section{Introduction}

By gradually expanding their activities, modern banks have exposed themselves to a broader risk spectrum. In response, they have developed large-scale risk-management systems to monitor risks within their banking and trading books. Over the past 15 years, these internal risk models have been increasingly used by banking regulators to impose on banks minimum levels of capital. If inaccurate, in-house risk assessments can lead to inappropriate levels of regulatory capital. Hence, the validation process of internal risk models turns out to be of paramount importance to guarantee that banks have adequate capital to cope with unexpected surges in losses and long freezes in financial markets. Nevertheless, the recent financial turmoil has cast serious doubt on current practices and calls for a more rigorous examination of banks' risk models. Following a series of risk management failures (Stulz, 2008, 2009), new proposals on capital regulation have flourished at an unprecedented pace (Basel Committee on Banking Supervision, 2009a). In this context of profound regulatory uncertainty, it has never been so imperative for banks to prove that their risk-management systems are sound.

\footnotetext{
* Corresponding author. Tel.: +33 1396794 11; fax: +33 139377085 .

E-mail address: perignon@hec.fr (C. Pérignon).
}

In this paper, we analyze the process by which banks appraise the validity of their risk models. Using a sample that includes the largest commercial banks in the world, our analysis reveals a key inconsistency in the way banks validate their models. We uncover that most banks use inappropriate data when testing the accuracy of their risk models. In particular, we document that a large fraction of banks artificially boost the performance of their models by polluting their profit-and-loss $(\mathrm{P} / \mathrm{L})$ with extraneous profits such as intraday revenues, fees, commissions, net interest income, and revenues from market making or underwriting activities.

In order to understand the inconsistency identified in this paper, consider a simple bank that only trades one asset, say asset A. To measure its market risk exposure and determine its regulatory capital, the bank typically computes its 1-day ahead 99\% Value-at-Risk (VaR), which is simply the VaR of asset A times the number of units owned at the end of a given day. ${ }^{1}$ The "perimeter" of the VaR model includes all trading positions that are marked-tomarket, i.e., the trading book of the bank. Periodically, the banking regulator checks whether the VaR model is producing accurate figures. To do so, it compares the daily $\mathrm{P} / \mathrm{L}$ of the trading portfolio to the daily VaR, a process known as backtesting. If the model is

\footnotetext{
1 The market-wide 1-day ahead 99\% VaR indicates the amount of money a bank can loose on proprietary trading over the next day, using a $99 \%$ confidence interval. Banks compute firm-level VaR using parametric models (e.g. Monte Carlo) or nonparametric models (e.g. historical simulation).
} 
correctly specified, the bank should experience a VaR exception (i.e. $\mathrm{P} / \mathrm{L}$ lower than VaR) one percent of the time, that is 2.5 days per year. To formally validate its model, the bank faces two key requirements. First, as VaR is based on yesterday's positions, the P/L used in backtesting must imperatively reflect the gains and losses that would result from yesterday's positions. Second, the P/L must only include items that are used to compute the VaR. As a result, it should not comprise intraday trading revenues (due to changes in the number of assets owned) and revenues and fees from activities that are not included in the risk model perimeter. If it does, the $\mathrm{P} / \mathrm{L}$ is contaminated and backtesting may be severely flawed.

The issue of $\mathrm{P} / \mathrm{L}$ contamination is not new. Indeed, it was already mentioned by the Bank for International Settlements (BIS) in the 1996 Amendment of the Basel Accord:

\begin{abstract}
"While this is straightforward in theory, in practice it complicates the issue of backtesting. For instance, it is often argued that value-at-risk measures cannot be compared against actual trading outcomes, since the actual outcomes will inevitably be "contaminated" by changes in portfolio composition during the holding period. According to this view, the inclusion of fee income together with trading gains and losses resulting from changes in the composition of the portfolio should not be included in the definition of the trading outcome because they do not relate to the risk inherent in the static portfolio that was assumed in constructing the value-at-risk measure. [...] To the extent that the backtesting program is viewed purely as a statistical test of the integrity of the calculation of the value-at-risk measure, it is clearly most appropriate to employ a definition of daily trading outcome that allows for an "uncontaminated" test."
\end{abstract}

\section{Basel Committee on Banking Supervision, BIS, January 1996}

To date, and to the best of our knowledge, the literature has remained remarkably silent on how widespread $\mathrm{P} / \mathrm{L}$ contamination is and what are the real consequences on risk model validation. As a matter of fact, while regulators typically acknowledge the potential danger of using contaminated $\mathrm{P} / \mathrm{L}$, the transposition of the Market Risk Amendment of the Basel Accord in national law remains vague. In Europe for instance, the directive 2006/49/EC on the Capital Adequacy of Investment Firms and Credit Institutions states that competent authorities may require institutions to perform backtesting on changes in portfolio value that would occur were end-of-day positions to remain unchanged, or excluding fees, commissions, and net interest income, or both. ${ }^{2}$ In the US, at the time the Market Risk Amendment to the Basel Accord was adopted in the mid-1990s, a VaR exception was defined as the condition when the contaminated $\mathrm{P} / \mathrm{L}$ is less than the VaR. In 2006, a joint Notice of Proposed Rulemaking entitled "Risk-Based Capital Standards: Market Risk" originated from the Board of Governors of the Federal Reserve System, the Federal Deposit Insurance Corporation, the Office of the Comptroller of the Currency, and the Office of Thrift Supervision. Among the changes proposed by the agencies was the exclusion of fees, commissions, reserves, and net interest income for the trading $\mathrm{P} / \mathrm{L}$ used for regulatory backtesting. The second modification suggested by the agencies was to base regulatory backtesting on uncontaminated $\mathrm{P} / \mathrm{L}$. While most of the leading US banks agreed that the new requirement would make more sense than the

\footnotetext{
2 The transposition of the Directive 2006/49/EC in national law has been completed for all the major EU member states. For a list of national transpositions of the Directive 2006/49/EC within EU member states, see http://www.c-ebs.org/documents/Supervisory-Disclosure/spreadsheets/rules/Rules_directive2006-49.aspx.
}

current practice, they claim that it would prove extremely burdensome. $^{3}$

In this paper, we systematically examine the extent to which banks use contaminated $\mathrm{P} / \mathrm{L}$ and investigate the economic impact of current risk management practices. To do so, we collect specific information on risk management from the annual reports of the largest 200 US and international commercial banks. In a first set of results, we find that over the period 2005-2008, less than $6 \%$ of the largest commercial banks in the world evaluate their risk models using the appropriate "uncontaminated" data. This proportion has remained pretty constant over the sample period and in particular has not increased during the recent financial crisis. Moreover, we uncover that only $28.2 \%$ of the sample banks screen out intraday revenues, and $7.1 \%$ of the sample banks do remove fees and commissions from their $\mathrm{P} / \mathrm{L} .{ }^{4}$ We also show that the use of clean data is more popular among the largest banks and also more common in Europe.

In a second set of results, we show that data contamination has a substantial economic impact on backtesting outcomes. In particular, we find that banks using contaminated data have much fewer days with trading losses and much fewer VaR exceptions than banks that rely on uncontaminated data. While the average number of VaR exceptions is 3.18 per year for the entire sample, it is equal to 6.12 for banks that use uncontaminated data. From a related perspective, a direct impact of inflating $\mathrm{P} / \mathrm{L}$ with fees and intraday trading revenues is to lower the rejection rate of standard validation techniques used by banking regulators. Using the "traffic light" approach developed and used by the Basel Committee, we estimate that $23.5 \%$ of the risk models are rejected when tested with uncontaminated $\mathrm{P} / \mathrm{L}$, whereas only $10.8 \%$ of the risk models are rejected when tested with $\mathrm{P} / \mathrm{L}$ that include both fees and intraday trading revenues. Furthermore, under the current regulatory framework, banking regulators increase capital requirements for banks experiencing an excessive number of VaR exceptions. As contamination tends to lower the number of exceptions, it mechanically reduces the penalty imposed by banking regulators. A back-of-the-envelope computation suggests that, for an average sample bank, data contamination can lead to a $17 \%$ reduction in market-risk induced capital.

Several multivariate tests further back up our results. In particular, Poisson regressions confirm that the type of $\mathrm{P} / \mathrm{L}$ data used by banks materially impacts backtesting results. Even after controlling for bank-specific characteristics, risk taking, VaR methodology, market conditions as well as the regulatory environment, we estimate that banks that employ uncontaminated $\mathrm{P} / \mathrm{L}$ experience significantly more VaR exceptions. Reassuringly, ancillary specifications reveal that our results are robust to the potential endogeneity of banks' decision to disclose specific information on backtesting.

Next, we investigate how $\mathrm{P} / \mathrm{L}$ contamination affects the performance of standard statistical tests used to backtest VaR models. These statistical tests are routinely used by risk managers and banking regulators to validate models and, if needed, penalize banks with poorly-performing risk-management systems. We conduct a Monte Carlo experiment to measure the sensitivity of each test to contaminated $\mathrm{P} / \mathrm{L}$. Using a battery of backtesting methods and contamination specifications, we show that $\mathrm{P} / \mathrm{L}$ contamination severely distorts conclusions about model accuracy. In particular, the average rejection rates of common VaR evaluation tests vary from being six times too high to being two times too low

\footnotetext{
${ }^{3}$ Public comments from US banks on the 2006 Risk-Based Capital Standards proposal can be found on http://www.federalreserve.gov/generalinfo/foia/ index.cfm?doc_id=R\%2D1266\&doc_ver=1.

4 In the following, the term "fees and commissions" refers to fees, commissions, net interest income, reserves, revenues from market-making, and revenues from underwriting activities.
} 


\section{دريافت فورى ـ ـ متن كامل مقاله}

\section{ISIArticles}

مرجع مقالات تخصصى ايران

ل امكان دانلود نسخه تمام متن مقالات انكليسى ل امكان دانلود نسخه ترجمه شده مقالات ل يذيرش سفارش ترجمه تخصصى $\checkmark$ ل امكان جستجو در آرشيو جامعى از صدها موضوع و هزاران مقاله ل امكان دانلود رايكان r صفحه اول هر مقاله

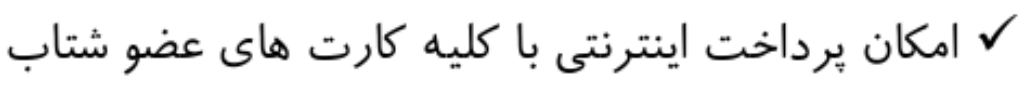
ل دانلود فورى مقاله پِ از برداخت آنلاين

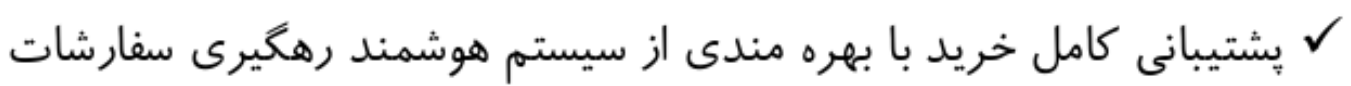

